\title{
Research Note \\ EFFECT OF PLANT GROWTH REGULATORS ON GROWTH AND YIELD OF BRINJAL AT KHAJURA, BANKE
}

\author{
M. D. Sharma \\ Institute of Agriculture and Animal Sciences, Rampur, Chitwan
}

\begin{abstract}
A field study was conduced in split-plot design with three replications to assess the effect of plant growth regulators (PGRs) on morphological characters and yield of brinjal cvs. Pusa Purple Long (PPL) and Pusa Purple Cluster (PPC) as main plot factor at Khajura, Banke district during summer-rainy season of 2004. The sub-plot treatments composed of fresh water (control), 40 ppm NAA, 10 ppm GA , 2 ppm 2,4-D, 300 ppm ethephon, $30 \mathrm{ppm}$ BAP and $5 \mathrm{ppm}$ triacontanol. The first spray was at flowering stage and the others at 20 days interval. The PGRs had no significant effect on plant height and stem diameter at the end of crop period and days to $100 \%$ plant flowering whereas the cultivars differed significantly. The PPL was earlier to $100 \%$ plant flowering, which took 33 days after transplanting. The treatments had no significant influence in fruit number per plant and fruit yield. The interaction effect showed that the. PPL did not produced statistically different fruit number per plant with respect to growth regulators, while it had significantly higher fruit yield $(17.76 \mathrm{t} / \mathrm{ha})$ at $40 \mathrm{ppm} \mathrm{NAA}$ than that at $10 \mathrm{ppm} \mathrm{GA}$ and $30 \mathrm{ppm}$ BAP. The PPC produced significantly higher fruit number per plant and higher fruit yield $(\mathrm{t} / \mathrm{ha})$ at $30 \mathrm{ppm}$ BAP than all other treatments except 5ppm triacontanol.
\end{abstract}

Key words: Growth regulators, cultivar, season, marketable, unmarketable, yield

\section{INTRODUCTION}

Brinjal (Solanum melongena L.) is an important vegetable crop, particularly of the Terai region of Nepal. Poor fruit set and low yield are the major problems. Plant growth regulators have been reported to improve germination, growth, fruit set, fresh vegetable and seed yields and yield quality (Saimbhi, 1993). Application of plant growth regulators as seed treatment and seedling root dip at transplanting have been found effective in enhancing germination and seedling growth, and in reducing transplanting shock. In pot experiment on brinjal, Das and Prusty (1972) reported that GA at 10 ppm enhanced seed germination. Sadawarte and Gupta (1968) also reported $24 \mathrm{~h}$ soaking of brinjal seeds in GA at $40 \mathrm{ppm}$, IAA at $50 \mathrm{ppm}$ or NAA at 25 ppm improved seed germination. Similarly, Sambasiva Rao et al. (1980) recorded dipping of brinjal seedling roots in NAA at 0.1 or $0.2 \mathrm{ppm}$ for 24 hours influenced growth and development. Bisaria and Bhatnagar (1978) obtained higher yield with foliar sprays of IAA at $20 \mathrm{ppm}$. Gupta (1971) reported that eggplant seeds treated with GA, IAA or NAA at 10 ppm significantly enhanced germination than at higher concentration or control. Hooda et al. (1985) reported higher fruit yield with cytozyme seed treatment at $10 \%$ and foliar spray at 1.25\%. Foliar spray of mixatol at 4 ppm four weeks after transplanting produced the highest fruit yield (Shukla and Prabhakar, 1988). Plant growth regulators can also be used to stimulate parthenocarpic fruit development in brinjal. Foliar spray of 2,4-D at $0.00025 \%$ to freshly opened flower cluster induced parthenocarpy in brinjal. Patel et al. (1997) reported that the Surati Ravaiya with application of 2,4-D at 4 ppm produced higher yield (54.11 t/ha) than with control treatment $(33.07 \mathrm{t} / \mathrm{ha})$. This study was conducted to assess the effect of various plant growth regulators on growth and yield of brinjal.

\section{MATERIALS AND METHODS}

This study was conducted in split plot design to assess the effect of various growth regulators on fruit set and yield with three replications at Khajura, Banke during summer-rainy season of 2004. The two cultivars Pusa Purple Long and Pusa Purple Cluster were main-plot factors and the applications of growth regulators such as control (Fresh water), 40ppm naphthalene acetic acid (NAA); 10ppm gibberellic acid (GA); 2 ppm 2,4dichlorophenoxyacetic acid (2,4-D); 300ppm ethephon (Kripon); 30ppm benzyl adenine purine (BAP) and 5 ppm triacontanol (Ki-plan) were sub-plot factors. The individual plot size was $5.4 \mathrm{~m}^{2}$ consisting of 30 plants. 
The field was ploughed twice, first with disc plough and the second with cultivator. Farm yard manure (FYM)@30t/ha and chemical fertilizers@ 40:60:60: NPK kg / ha were applied in each plot separately at the time of final land preparation. Fifty-five days old seedlings $\left(20^{\text {th }}\right.$ February nursery sowing) were transplanted on $16^{\text {th }}$ April 2004 at $60 \mathrm{~cm}$ row to row and $30 \mathrm{~cm}$ plant-to-plant distance. Four side dresses each with $20 \mathrm{~kg} \mathrm{~N} / \mathrm{ha}$ were made at regular interval of 20 days. Surface irrigation was practiced at 4-7 days interval in summer and when necessary in rainy season. Weeding was practiced along with side dresses. Days to $50 \%$ and $100 \%$ flowering after transplanting were recorded. Plant height and stem diameter were measured thrice at an interval of 30 days. Average number of marketable, unmarketable and borer infected fruits per plant were counted. The marketable, unmarketable and borer infected yields were recorded. The MSTAT-C computer package was used to analyze the data.

\section{RESULTS AND DISCUSSION}

\section{Morpho-phenological characters}

The morphological characters, such as plant height and stem diameter were measured at three growth stages. The first measurement at the flowering stage, the second at prolific fruiting stage and the third at the end of crop period. The growth rate of plant height was very high between flowering and first harvest periods and then declined. The growth rate of stem diameter was more stable than that of plant height. The Pusa Purple Cluster had significantly thicker stem diameter at all growth stages. Hence, the Pusa Purple Cluster had taller plants with thicker stem diameter than Pusa Purple Long.

The different plant growth regulators employed did not influence both plant height and stem diameter significantly (Table 1). The Pusa Purple Long and Pusa Purple Cluster differed significantly in plant height and stem diameter at all growth stages. The cv. Pusa Purple Long produced flowers significantly earlier than Pusa Purple Cluster $(\mathrm{P}<0.01)$. The period from transplanting to 100 percent flowering was 33 days in Pusa Purple Long (Table 2). The growth regulators did not influence days to $100 \%$ plant flowering significantly in both cultivars.

Table 1. Effects of different PGRs on brinjal morphological characters of cvs. Pusa Purple Long and Pusa Purple Cluster at Khajura, Nepalgunj during summer-rainy season, 2004

\begin{tabular}{|lcc|}
\hline Treatments & PH on $\mathbf{1 0}^{\text {th }^{\text {th }}}$ July & SD on $\mathbf{1}^{\text {th }^{\text {th }}}$ July \\
\hline Control & 66.40 & 1.58 \\
NAA 40 ppm & 63.23 & 1.59 \\
GA3 10 ppm & 66.90 & 1.57 \\
2,4-D 2ppm & 64.65 & 1.47 \\
Ethephon 300 ppm & 62.00 & 1.64 \\
BAP-30 ppm & 68.60 & 1.51 \\
Triacontanol-5ppm & 67.00 & 1.52 \\
LSD & ns & ns \\
CV\% & 9.70 & 7.82 \\
\hline
\end{tabular}

$\mathrm{PH}=$ Plant Height, $\mathrm{ns}=$ Non-significant; $\mathrm{SD}=$ Stem Diameter

Table 2. Varietal differences in Days to $100 \%$ flowering, plant height and stem diameter at Khajura, Banke during summer-rainy season, 2004

\begin{tabular}{|lccc|}
\hline Treatments & Days to $\mathbf{1 0 0} \%$ flowering & Plant height on 10th July & Stem diameter on 10th July \\
\hline Pusa Purple Long & $33 \mathrm{~b}$ & $58 \mathrm{~b}$ & $1.391 \mathrm{~b}$ \\
Pusa Purple Cluster & $44 \mathrm{a}$ & $73 \mathrm{a}$ & $1.726 \mathrm{a}$ \\
P value & $<0.01 * *$ & $<0.05^{*}$ & $<0.01^{* *}$ \\
CV $\%$ & 5.66 & 9.7 & 7.82 \\
\hline
\end{tabular}

Mean within the column followed by the same letter/s do not differ significantly at $0.05\left(^{*}\right)$ and at 0.01 (**) level by DMRT

\section{Yield and yield components}

The growth regulators did not influence significantly in fruit number (marketable, total, unmarketable and 
borer infested) per plant and fruit yield (marketable and unmarketable) (Table 3). However, the treatments 30 ppm BAP, 40 ppm NAA and 5 ppm triacontahol applications produced higher yields than other treatments.

Table 3. Effects of different PGRs on yield attributes of brinjal at Khajura, Banke during summer-rainy season, 2004

\begin{tabular}{|c|c|c|c|c|c|}
\hline Treatments & MFN/Plant & MFY t/ha & UMFN/plant & BIFN/plant & UMFY t/ha \\
\hline Control & 5.83 & 12.46 & 4.00 & 4.00 & 7.31 \\
\hline NAA 40ppm & 6.50 & 14.98 & 4.00 & 3.66 & 7.57 \\
\hline GA3 10ppm & 5.50 & 10.72 & 4.50 & 4.16 & 7.87 \\
\hline 2,4-D 2ppm & 6.17 & 13.22 & 3.50 & 3.50 & 6.26 \\
\hline Ethephon 300ppm & 5.50 & 11.05 & 3.50 & 3.50 & 5.98 \\
\hline BAP 30ppm & 7.66 & 15.16 & 4.00 & 3.50 & 7.39 \\
\hline Triacontanol 5ppm & 6.16 & 14.15 & 4.00 & 3.83 & 8.74 \\
\hline LSD & ns & ns & ns & ns & ns \\
\hline $\mathrm{CV} \%$ & 29.92 & 23.70 & 21.81 & 21.12 & 27.25 \\
\hline
\end{tabular}

Note: MFN= Marketable Fruit Number, MFY= Marketable Fruit Yield, UMFN = Unmarketable Fruit Number, BIFN= Borer Infected Fruit Number and UMFY= Unmarketable Fruit Yield

In the. Pusa Purple Long the growth regulators did not produce significantly higher marketable fruit number per plant than that of control,while the. Pusa Purple Cluster produced significantly higher marketable fruit number per plant at BAP $30 \mathrm{ppm}$ than those at all other treatments (Table 4). The marketable fruit numbers of the Pusa Purple Long at 40 ppm NAA and 2 ppm 2,4-D and of the Pusa Purple Cluster at BAP 30 ppm were at par. The Pusa Purple Long produced significantly higher yield at $40 \mathrm{ppm}$ NAA than at $\mathrm{GA}_{3} 10$ ppm and 30 ppm BAP while, the yields at other treatments were at par. Sharma et al. (1992) reported that brinjal Pusa Purple Long sprayed with 300 ppm GA flowered earliest and had the highest number of fruits and yield per plant. The results do not follow this findings it might be associated with concentration of $\mathrm{GA}_{3}$. The Pusa Purple Cluster produced significantly higher yield at $30 \mathrm{ppm}$ BAP than those at all other treatments except 5 ppm triacontanol (Table 4).

Table 4. Interaction effects of different PGRs and varieties on marketable fruit number and yield of brinjal at Khajura, Banke during summer-rainy season, 2004

\begin{tabular}{|c|c|c|c|c|c|c|c|c|c|}
\hline Treatments & $\begin{array}{l}\text { Control } \\
\text { ppm }\end{array}$ & $\begin{array}{c}\text { NAA } 40 \\
\text { ppm }\end{array}$ & $\begin{array}{c}\text { GA3 } 10 \\
2 \mathrm{ppm}\end{array}$ & $\begin{array}{c}2,4-\mathrm{D} \\
300 \mathrm{ppm}\end{array}$ & $\begin{array}{l}\text { Ethephon } \\
30 \text { ppm }\end{array}$ & $\begin{array}{c}\text { BAP } \\
5 \mathrm{ppm}\end{array}$ & Triacontanol & LSD & $\mathrm{CV} \%$ \\
\hline MFNO PPL & $6.66 \mathrm{bc}$ & $8.33 \mathrm{ab}$ & $6.00 \mathrm{bc}$ & $7.00 \mathrm{a}-\mathrm{c}$ & $6.33 \mathrm{bc}$ & $5.33 \mathrm{bc}$ & $6.67 \mathrm{bc}$ & $2.891 *$ & 27.7 \\
\hline Per plant PPC & $5.00 \mathrm{bc}$ & $4.67 \mathrm{c}$ & $5.00 \mathrm{bc}$ & $5.34 \mathrm{bc}$ & $4.67 \mathrm{c}$ & $10.00 \mathrm{a}$ & $5.66 \mathrm{bc}$ & & \\
\hline MFYt/ha PPL & $13.52 \mathrm{a}-\mathrm{c}$ & 17.76ab & $9.71 \mathrm{c}$ & $14.79 \mathrm{a}-\mathrm{c}$ & $12.70 \mathrm{bc}$ & $11.08 \mathrm{c}$ & $14.70 \mathrm{abc}$ & $5.63^{*}$ & 25.53 \\
\hline PPC & $11.40 \mathrm{bc}$ & $12.20 \mathrm{bc}$ & $11.73 \mathrm{bc}$ & $11.66 \mathrm{bc}$ & $9.31 \mathrm{c}$ & $19.25 \mathrm{a}$ & $13.59 \mathrm{abc}$ & & \\
\hline
\end{tabular}

Note: $\mathrm{MFNO}=$ Marketable Fruit Number, MFY= Marketable Fruit Yield, PPL= Pusa Purple Long and PPC= Pusa Purple Cluster; Mean within the column followed by the same letter/s do not differ significantly at 0.05 levels by DMRT

Hence, 30ppm BAP was found most effective followed by $5 \mathrm{ppm}$ triacontanol in. Pusa Purple Cluster while 40ppm NAA, 2ppm 2,4-D and 5ppm triacontanol had shown positive effect on yield in the Pusa Purple Long.

\section{ACKNOWLEDGEMENTS}

This is a piece of work of the research program 'Improvement in fruit set of brinjal and chilli (041/059/ 060) operated under the financial support of National Agriculture Research and Development Fund (NARDF) during 2003 to 2006.

\section{REFERENCES CITED}

Bisaria, A. K. and V. K. Bhatnagar. 1978. Effect of growth regulators on growth and fruit yield in brinjal (Solanum menolgena L.). Indian J Hort. 35:381-383.

Das, R. C. and S. S. Prusty. 1972. Growth regulators effect on seed treated brinjal plants (Solanum melongena L.) with relation to vegetative development. Indian J. Hort. 29:334-335. 
Gupta, S. C. 1971. Effect of NAA, IAA and GA on germination of brinjal (Solanum menolgena L.) seeds. Indian J. Agric.l Res. 5(3): 215-216.

Hooda, R. S., A. S. Sindhu and M. L. Pandita. 1985. Effect of seedling treatment and foliar application of cytozyme on growth and yield of tomato, brinjal, and chillies. Haryana Agric. Univ. J. Res. 15:329-331.

Patel, M. N., C. K. Dint and R. B. Patel. 1997. Growth and yield of brinjal (Solanum menolgena L.) cv. Surati Ravaiya as influenced by 2,4-D and NAA. J. Appl. Hort. 3 (1-2): 112-114.

Sadawarte, K. T. and P. K. Gupta. 1968. Effect of seed treatment with plant growth regulators on germination, growth and yield of brinjal. Punjab Hort. J., 8: 95-99.

Saimbhi, M. S. 1993. Growth regulators on vegetable crops. In: K. L. Chadha and G. Kallo (eds.). Advances in Horticulture, vol. 6 (I). Malhotra Publishing House, New Delhi, India. pp. 619-642.

Sambasiva Rao, G., D. U. S. Rao and V. Surayanarayana. 1980. Effect of starters and naphthalene acetic acid in brinjal. Veg. Sci. 7: 129-132.

Sharma, A. K., R. S. Rattan and N. K. Pathania. 1992. Effect of plant growth regulators on yield and morphological traits I brinjal (Solanum menolgena L.). Agric. Sci. Digest Karnal 12(4): 219-222.

Shukla, V. and B. S. Prabhakar. 1988. Effect of mixatol on production potential of brinjal. Indian J. Hort. 43:403-407. 